\title{
Sistem Keamanan Anjungan Tunai Mandiri
}

\author{
John Reimon Batmetan, Triska Pinatik \\ Prodi Pendidikan Teknologi Informasi dan Komunikasi, Universitas Negeri Manado, Tondano. 95318
}

\begin{abstract}
ABSTRAK
Penelitian ini mengkaji studi literatur mengenai sistem keamanan pada anjungan tunai mandiri yang meliputi pengamanan PIN dan bentuk serangan pada keamanan ATM. Metode yang digunakan dalam pengamanan pada ATM adalah dengan penggunaan PIN untuk dapat melakukan akses dan transaksi melalui mesin ATM. Pengamanan PIN dilakukan dengan menggunakan proses kriptografi (enkripsi dan dekripsi) dengan menggunakan standar Triple DES (data encryption standard). Penggunaan ATM tidak terlepas dari perlunya menjaga sistem keamanan pada ATM. Dalam dokumen ini dijelaskan penggunaan metode kriptografi DES dan Triple DES. Saat ini sudah terdapat berbagai ancaman yang menyerang keamanan dalam penggunaan ATM seperti skimming, phishing.
\end{abstract}

Kata kunci: Automated Teller Machine, data encryption standard, phishing

\section{PENDAHULUAN}

\section{ATM (Automated Teller Machinel} Anjungan Tunai Mandiri) merupakan sebuah perangkat komputerisasi yang digunakan oleh suatu lembaga keuangan (bank) dalam upaya menyediakan layanan transaksi keuangan (pengambilan uang) di tempat umum tanpa membutuhkan adanya pegawai bank (teller).Pada mulanya penyediaan ATM adalah untuk memudahkan layanan pengambilan uang dari tabungan nasabah, akan tetapi seiring dengan perkembangan teknologi dan kebutuhan akan peningkatan layanan kepada para nasabah, penggunaan ATM telah meluas tidak hanya sebatas pengambilan uang saja. Saat ini sudah memungkinkan bagi para nasabah untuk melakukan transfer (pemindahbukuan) uang, pembayaran, pengecekan saldo, dan transaksi keuangan lain sebagainya cukup dengan menggunakan ATM. Secara umum, teknologi pada ATM merupakan suatu bentuk jaringan komputer yang tersebar. Jaringan ATMAdanya proses transaksi (komunikasi) antarkomputer yang melalui sebuah jaringan yang luas, isu mengenai keamanan merupakan isu yang perlu diperhatikan secara khusus. Hal ini tentunya untuk menjamin proses transaksi dapat terjadi dengan baik dan benar. Teknik pengamanan yang dilakukan. Sistem Keamanan ATM adalah dengan penggunaan personal identification number (PIN) sehingga hanya orang tertentu saja yang dapat mengakses atau pun melakukan transaksi pada ATM. Untuk pengaksesan pada mesin ATM para nasabah akan memiliki kartu dengan pita magnetik atau sebuah chip yang berfungsi sebagai tempat penyimpanan data seperti nomor kartu, nomor PIN, dan data keamanan lainnya.

Dalam sistem keamanan yang diterapkan pada ATM terdapat proses enkripsi data untuk menjaga keamanan data pribadi, seperti nomor PIN ataupun nomor kartu, dan juga untuk menjaga keamanan selama proses transaksi berlangsung (pada saat proses transaksi berlangsung terjadi komunikasi antara ATM dengan computer bank yang melalui jarring perbankan). Untuk menjamin keamanan pada ATM digunakan metode enkripsi data dengan teknik data encryption standard (DES); yang kemudian dikembangkan menjadi Triple DES 
guna meningkatkan keamanan data. Skema algoritma pada DES. Pada proses enciphering, setiap putarannya digunakan algoritma dengan model jaringan Feistel. Dengan demikian pada proses enciphering blok plaintext hasil permutasi awal akan dibagi menjadi dua bagian dengan ukuran masing-masing 32 bit. Di dalam jaringan Feistel inilah digunakan kunci internal terhadap fungsi transfromasi.

\section{Sistem Keamanan ATM}

Pada DES pembangkitan kunci dilakukan dengan menggunakan kunci eksternal yang diberikan sebelumnya. Proses pembangkitan kunci internal dilakukan dengan melakukan permutasi dan penggeseran bit ke kiri. Keseluruhan pembangkitan kunci internal dilakukan untuk proses deciphering (dekripsi) pada DES, operasi yang dilakukan merupakan kebalikan dari operasi yang dilakukan pada saat melakukan proses ciphering. Penggunaan DES sebagai standar kriptografi (pengamanan) data masih diperdebatkan dan pada DES terdapat celah keamanan yang cukup fatal yaitu penggunaan kunci dengan ukuran 56 bit. Penggunaan kunci dengan jumlah kemungkinan yang cukup "sedikit" ini (256 atau 72.057.594.037.927.936 kemungkinan) mengakibatkan rentan terhadap serangan keamanan. Electronic Frontier Foundation (EFE) pada tahun 1998 merancang dan membuat sebuah perangkat keras (DES cracker) dengan menggunakan metode exhaustive search key untuk memecahkan kunci pada DES dan diharapkan dapat berhasil menemukan kunci DES tersebut selama 5 hari. Setahun kemudian, penggunaan DES cracker dengan kolaborasi internet dapat menemukan kunci DES kurang dari 1 hari. Dikarenakan kelemahan tersebut kemudian dikembangkanlah DES sehingga menghasilkan standar yang disebut sebagai Triple DES.

\section{Pengamanan Pada ATM}

Pada sistem keamanan ATM umumnya menggunakan nomor PIN dengan kombinasi empat angka. Proses pembuatan nomor PIN tersebut menggunakan perhitungan sebagai berikut:

1. Ambil lima digit terakhir dari nomor rekening

2. Gabungkan kelima angka tersebut dengan 11 digit data validasi (data validasi diciptakan sendiri)

3. Keenambelas angka tersebut merupakan data yang menjadi data masukan untuk algoritma DES. Pada pemrosesan dengan algoritma DES digunakan kunci berukuran 16 digit yang kemudian disebut sebagai "kunci PIN".

4. Dari hasil pemrosesan dengan DES diambil 4 digit pertama kemudian diubah ke dalam bentuk desimal - penggunaan DES akan menghasilkan bilangan dengan satuan heksadesimal. Empat digit tersebut kemudian disebut sebagai "PIN alami".

5. Dari PIN alami tersebut kemudian ditambahkan dengan 4 digit yang disebut sebagai offset sehingga menghasilkan nomor PIN yang akan digunakan oleh nasabah.

\section{Serangan Pada Keamanan ATM}

Penggunaan teknik enkripsi (kriptografi) tidak selalu menjamin seratus persen pada sistem keamanan ATM. Berbagai kejahatan atau kecurangan terhadap sistem keamanan ATM tidaklah sedikit. Kejahatan yang terjadi mulai dari tindakan yang cukup sederhana, seperti pencopetan, penodongan, ataupun perampokan, sampai penggunaan teknologi yang cukup canggih yaitu penggunaan teknologi untuk mengetahui nomor rekening, PIN nasabah, ataupun melakukan duplikasi data keamanan nasabah. Berikut akan dijelaskan beberapa ancaman keamanan pada penggunaan ATM. 


\section{Pencurian uang}

Salah satu bentuk paling sederhana dalam melakukan kecurangan di ATM adalah dengan mencuri uang hasil pengambilan yang dilakukan oleh nasabah. Tentunya pencurian di sini bukan dengan menodong nasabah setelah melakukan transaksi melainkan menggunakan alat "penyimpan" uang yang ditempelkan pada mesin ATM (gambar 10). Alat "penyimpan" uang Alat yang digunakan dalam metode ini adalah sebuah "duplikat" tempat keluarnya uang pada mesin ATM. Dengan demikian nasabah yang akan melakukan transaksi tidak mencurigai perangkap tersebut. Saat nasabah melakukan transaksi tentunya diharapkan uang akan keluar dari mesin ATM. Namun, dikarenakan uang tersebut disimpan di perangkap tersebut, seolah-olah proses yang terjadi adalah mesin ATM kehabisan uang, sudah tidak ada lagi lebar uang yang tersisa di dalam mesin ATM tersebut. Setelah merasa proses transaksi gagal maka nasabah (sang korban) meninggalkan mesin ATM dan tak lama setelah itu dang pelaku kejahatan mengambil "tabungan"-nya di ATM tersebut.

\section{Pencurian kartu}

Proses pencurian kartu yang dimaksud di sini adalah dengan menggunakan alat yang "ditanamkan" ke dalam mesin ATM yaitu pada lubang/slot untuk memasukkan kartu ATM Fungsi alat tersebut adalah seolah-olah mengakibatkan situasi dimana kartu "tertelan" oleh mesin ATM sehingga nasabah tidak sadar bahwa sebenarnya kartu ATM miliknya telah dicuri. Pada saat nasabah (sang korban) kebingungan dengan situasi tersebut, sang pelaku kejahatan seolah-olah datang untuk membantu dan meminta nasabah tersebut untuk memasukkan nomor PIN kembali dengan dalih untuk memastikan proses di ATM tersebut; secara diam-diam pelaku kejahatan mengintip nomor PIN nasabah. Dikarenakan kartu ATM tidak dapat terselamatkan nasabah tersebut dianjurkan untuk melapor ke pihak yang terkait. Setelah nasabah pergi sang pelaku kejahatan dapat melakukan transaksi dengan kartu yang"disimpan" di mesin ATM dan ia juga mengetahui nomor PIN kartu tesebut. Dengan menggunakan metode pencurian kartu tersebut, tentunya hal yang menjadi perhatian utama bagi pelaku kejahatan adalah mengenai nomor PIN dari kartu ATM tersebut agar dapat digunakan. Bila menggunakan cara yang telah disebutkan sebelumnya tentunya dapat menimbulkan kecurigaan bagi sang korban. Oleh karena itu, terdapat beberapa teknik lain yang digunakan untuk mendapatkan nomor PIN dari nasabah yang menjadi korban kejahatan tersebut,yaitu: Penggunaan kamera tersembunyi Teknik ini merupakan teknik yang sederhana. Dengan menempatkan posisi kamera di tempat yang strategis dan tersembunyi dengan baik, pelaku kejahatan dapat dengan mudah melihat nomor PIN yang dimasukkan oleh nasabah (sang korban). pencatatan data elektronik di mesin ATM tersebut. Dengan melakukan penyadapan terhadap akses data tersebut maka dapat diambil data-data penting yang disimpan di dalam mesin ATM tersebut salah satunya adalah nomor PIN nasabah.

\section{Skimming}

Metode skimming dapat dipahami sebagai metode "penyaringan" data pada kartu ATM nasabah. Untuk kasus kejahatan dengan metode skimming digunakan alat yang disebut sebagi "skimer" (gambar 14). Fungsi alat ini adalah untuk "menyaring" data-data yang terdapat di dalam kartu ATM nasabah. Penempatan skimer diletakkan di sekitar mesin ATM sehingga seolah-olah alat tersebut merupakan bagian dari mesin ATM. Cara kerja alat ini adalah dengan menyalin data-data yang ada di dalam pita magnetic kartu ATM pada saat digesekan di alat tersebut. Setelah data di dalam kartu ATM 
disalin maka pelaku kejahatan dapat melakukan duplikasi kartu ATM dan melakukan transaksi pengambilan uang di ATM layaknya seorang nasabah.

\section{Phishing}

Phising merupakan bentuk kejahatan dengan manggunakan teknik rekayasa sosial. Pada penggunaan teknik ini sang pelaku kejahatan mencoba untuk mencari tahu dan mengambil data-data pribadi nasabah dengan memposisikan dirinya sebagai seseorang ataupun lembaga yang dapat dipercaya dalam melakukan transaksi ataupun komunikasi secara elektronik. Umumnya penggunaan teknik penipuan ini dilakukan dengan menggunakan media internet, email, ataupun telepon. Pelaku akan mengaku sebagai orang yang dapat dipercaya dalam melaksanakan suatu kegiatan atau transaksi tertentu. Pada bentuk penyerangan menggunakan ATM umumnya saat ini adalah dengan menggunakan fasilitas transfer yang sudah dapat dilakukan melalui mesin ATM. Dengan menggunakan nomor rekening tujuan tertentu maka proses transfer dilakukan dan pada saat itu juga datadata nasabah dapat diketahui oleh pelaku kejahatan. Dalam proses komunikasi dengan menggunakan jaringan komputer tentunya dibutuhkan informasi mengenai pengirim dan penerima. Dengan menempatkan diri sebagai penerima, sang pelaku kejahatan tentunya dapat mengetahui data-data mengenai sang pengirim, dalam hal ini adalah nasabah (sang korban). Dengan menggunakan metode ini, pelaku kejahatan akan mengetahui data-data dari nasabah terutama terkait dengan rekening, alamat, ataupun data-data lain yang terkait. Teknik phishing yang dilakukan dengan media ATM adalah untuk mengetahui data-data yang terdapat di dalam pita magnetic (track 2) karena pada pita magnetic tersebut tersimpan data-data rekening ataupun finansial nasabah diantaranya adalah card verification value (CVV) dan card validation code (CVC). Kedua data tersebut merupakan data yang digunakan oleh Visa dan MasterCard yang merupakan data untuk melakukan transaksi. Dengan mendapatkan data-data tersebut, sang pelaku dapat membuat duplikat kartu dan menggunakan kartu tersebut dalam melakukan transaksi sehari-hari tanpa perlu pusing memikirkan saldo yang mencukupi atau tidak. Seandainya kartu tersebut sudah tidak bisa dipakai lagi, maka yang dilakukan adalah menggunakan kartu lain milik nasabah yang lainnya.

Umumnya bentuk serangan dengan teknik phishing saat ini cukup banyak terjadi pada media internet, salah satunya pada bidang perbankan dengan adanya layanan internet banking. Melalui layanan ini nasabah dapat melakukan transaksi perbankan seperti transfer dana, pembayaran, dan lain sebagainya. Penggunaan teknik dengan media internet umumnya dilakukan terhadap pengguna layanan keuangan. Untuk layananlayanan tertentu yang tersedia dengan menggunakan media internet dibutuhkan data-data pribadi dari pengguna. Sebagai contoh adalah untuk kegiatan bisnis sebutlah tranfser dana. Dengan adanya layanan secara online tentunya akan mempermudah nasabah dalam menjalankan transaksinya. Nasabah tidak perlu lagi harus datang ke bank hanya untuk melakukan transaksi transfer dana.

Pada kesempatan inilah seorang phisher (pelaku phishing) menjalankan aksinya. Dengan membuat sebuah halaman web yang menyerupai dengan halaman web dari pihak perbankan, phisher menyamar dan berlaku layaknya pihak perbankan tersebut. Untuk melakukan proses transaksi tentunya membutuhkan data-data pribadi meliputi nomor rekening, nomor identitas, nomor kontak, dan lain sebagainya. Tentunya dengan tidak menaruh rasa curiga, nasabah memberikan data-data yang memang "dibutuhkan" tersebut. Dengan demikian, sang 
phisher telah mendapatkan "ikan" yang dicarinya. Secara tidak langsung, phisher telah memiliki data-data yang dibutuhkan untuk mengetahui keuntungan apa saja yang kira-kira bisa dia dapatkan dari sang korban.

Bahaya yang ditimbulkan dari tindak kriminal phishing ini tidak hanya merugikan secara teknologi saja tetapi juga dapat berdampak ke lingkungan sosial. Kerugian utama tentunya akan dialami oleh pihak perbankan karena dengan tindak criminal tersebut selain menghilangkan aset dan kekayaan juga mengakibatkan kehilangan kepercayaan publik. Secara damapak sosial, tentunya tindak phishing ini sangat mempengaruhi terutama terkait dengan keamanan pribadi (privasi). Oleh karenanya, peningkatan keamanan data menjadi perhatian utama dalam menangani kasus ini.

\section{METODE PENELITIAN}

\section{Metode pengumpulan data}

Metode Pengumpulan Data Metode pengumpulan data primer dilakukan dengan penyebaran kuesioner melalui google forms untuk memperoleh data. Dalam penelitian ini peneliti menggunakan Skala Likert. Skala likert merupakan suatu skala psikometrik yang paling banyak digunakan dalam riset berupa survey . Skala ini diambil dari nama Rensis Likert, yang menerbitkan suatu laporan yang menjelaskan penggunaan skala ini . Pada saat menanggapi pertanyaan dalam skala Likert, responden menentukan tingkat persetujuan mereka terhadap suatu pernyataan dengan memilih salah satu dari pilihan yang tersedia. Biasanya disediakan lima pilihan skala dengan format seperti: 1 = Sangat Tidak Setuju, 2 = Tidak Setuju, 3 = Ragu-Ragu, $4=$ Tidak setuju, $5=$ Sangat tidak setuju.

Untuk mendapatkan data yang bersifat ordinal dan diberi skor sebagai berikut :
Tabel 1. Skor likert

\begin{tabular}{cccccc}
\hline PK & STS & TS & RR & S & SS \\
\hline & 1 & 2 & 3 & 4 & 5 \\
\hline
\end{tabular}

Keterangan :

PK : Pertanyaan Kuesioner STS : Sangat Tidak Setuju TS : Tidak Setuju RR : Ragu-ragu S : Setuju SS : Sangat Setuju

\section{HASIL DAN PEMBAHASAN}

Dalam penelitian ini, peneliti membagikan kuesioner kepada dosen, staff karyawan, dan mahasiswa di Universitas Negeri Manado yang berisi 5 pertanyaan yang sudah mewakili kelima aspek dengan menggunakan media google forms. Pengguna mengisi kuesioner yang sudah dibagikan berdasarkan pengalamannya (apa yang dilihat dan dirasakan) pada saat menggunakan Mesin ATM d. Setiap pertanyaan dari kuesioner tersebut memiliki tujuan untuk mengukur tingkat menurut penerimaan user, yang selanjutnya akan di nilai menggunakan skala Likert. Pertanyaan tersebut telah mewakili kelima aspek tersebut, diantaranya yaitu learnability, eficiency, memorability, errors, dan satisfaction. Dari kuesioner yang telah diberikan kepada responden, data dianalisa menggunakan model skala likert.

Rumus Index $\%=$ Total Skor $/ \mathrm{Y}$ x 100

$\mathrm{Y}=$ Skor tertinggi likert $\mathrm{x}$ jumlah responden (Angka Tertinggi 5) "Perhatikan Bobot Nilai"

$\mathrm{X}=$ Skor terendah likert $\mathrm{x}$ jumlah responden (Angka Terendah 1) "Perhatikan Bobot Nilai" 
Tabel 2 range jawaban

\begin{tabular}{ll}
\hline \multicolumn{1}{c}{ Jawaban } & \multicolumn{1}{c}{ Keterangan } \\
\hline $0 \%-19.99 \%$ & Sangat tidak setuju \\
\hline $20 \%-39.99 \%$ & Tidak setuju \\
\hline $40 \%-59.99 \%$ & Ragu-Ragu \\
\hline $60 \%-79.99 \%$ & Setuju \\
\hline $80 \%-100 \%$ & Sangat Setuju \\
\hline
\end{tabular}

Analisa Setelah penyebaran kuesioner yang diberikan kepada 30 responden, makaselanjutnya dilakukan rekap terhadap hasil kuesioner yang diperoleh.

Tabel 3. Rekapitulasi Jawaban

\begin{tabular}{|c|c|c|c|}
\hline No & Pertanyaan & $\begin{array}{l}\text { Presentase } \\
\text { nilai }\end{array}$ & Keterangan \\
\hline 1. & $\begin{array}{l}\text { Melakukan } \\
\text { Transaksi dengan } \\
\text { ATM }\end{array}$ & $86 \%$ & $\begin{array}{l}\text { Sangat } \\
\text { Setuju }\end{array}$ \\
\hline 2. & $\begin{array}{l}\text { Proses lebih cepat } \\
\text { dengan ATM }\end{array}$ & $79,3 \%$ & Setuju \\
\hline 3. & $\begin{array}{l}\text { ATM } \\
\text { mempermudah } \\
\text { transaksi antar bank }\end{array}$ & $80 \%$ & $\begin{array}{l}\text { Sangat } \\
\text { Setuju }\end{array}$ \\
\hline 4. & $\begin{array}{l}\text { ATM Aman untuk } \\
\text { melakukan } \\
\text { transaksi }\end{array}$ & $81,3 \%$ & $\begin{array}{l}\text { Sangat } \\
\text { setuju }\end{array}$ \\
\hline 5. & $\begin{array}{l}\text { Banyak Terjadi } \\
\text { kejahatan dan } \\
\text { pemalsuan carding } \\
\text { di ATM }\end{array}$ & $83,3 \%$ & $\begin{array}{l}\text { Sangat } \\
\text { Setuju }\end{array}$ \\
\hline
\end{tabular}

Pada table 3 diatas menunjukan nilai kepuasan/ penerimaan user (acceptance) terhadap tiap butir pertanyaan yang diajukan. Dapat dilihat bahwa untuk Sistem keamanan ATM memiliki presentase nilai. dalam skala likert. Ini dapat diartikan bahwa Sistem keamanan ATM mudah dikenali oleh pengguna dari segi interface. Jika disesuaikan dengan Sistem keamanan ATM, data dikatakan bahwa Sistem keamanan ATM telah memiliki nilai yang sangat baik. Hal ini ditunjukkan dengan nilai hasil pada lima atribut sebagai berikut :
Nilai atribut "Melakukan Transaksi dengan ATM" sebesar $86 \%$ yang menunjukkan bahwa android telah memiliki nilai aspek Learnability. Nilai atribut "Proses lebih cepat dengan ATM" sebesar 79,3\% menunjukkan bahwa Android telah memiliki nilai aspek Efficiency. Nilai atribut "ATM mempermudah transaksi antar bank "sebesar 80\% menunjukkan bahwa Android telah memiliki nilai aspek Memorability. Nilai atribut "ATM Aman untuk melakukan transaksi" sebesar $81,3 \%$ dan atribut "Simbolsimbol gambar mudah dipahami" sebesar 74\% membuat Android dapat dikatakan telah meminimalisasi aspek Errors. Dan dari keseluruhan atribut yang memiliki nilai ratarata di atas 3, menunjukkan jika Sisstem keamanan ATM telah mempunyai aspek Satisfaction yang baik.

\section{KESIMPULAN}

ATM (Automated Teller Machine / Anjungan Tunai Mandiri) merupakan sebuah perangkat komputerisasi yang digunakan oleh suatu lembaga keuangan (bank) dalam upaya menyediakan layanan transaksi keuangan (pengambilan uang) di tempat umum tanpa membutuhkan adanya pegawai bank (teller). penggunaan ATM telah meluas tidak hanya sebatas pengambilan uang saja. Saat ini sudah memungkinkan bagi para nasabah untuk melakukan transfer (pemindahbukuan) uang, pembayaran, pengecekan saldo, dan transaksi keuangan lain sebagainya cukup dengan menggunakan ATM. Secara umum, teknologi pada ATM merupakan suatu bentuk jaringan komputer yang tersebar. Jaringan ATMAdanya proses transaksi (komunikasi) antarkomputer yang melalui sebuah jaringan yang luas, isu mengenai keamanan merupakan isu yang perlu diperhatikan secara khusus. Hal ini tentunya untuk menjamin proses transaksi dapat terjadi dengan baik dan benar. Teknik pengamanan yang dilakukan. 


\section{DAFTAR PUSTAKA}

[1] APACS. Card Fraud: the facts 2002. United Kingdom. 2002

[2] Bond, Michael. Understanding Security APIs. University of Cambridge. 2004.

[3] Bond, Mike dan Piotr Zielinski. Decimalisation Table Attacks for PIN Cracking. University of Cambridge. 2003.

[4] Istnick, Anna C. dan Emilio Caligaris. ATM Fraud and Security. DIEBOLD. Amerika Serikat. 2003.

[5] Litan, Avivah. Criminals Exploit Consumer Bank Account and ATM System Weaknesses. Gartner. 2005.

[6] Steel, Graham. Formal Analysis of PIN Block Attacks. University of Edinburgh. Scotland. 2006.

[7] Vellani, Karim H. dan Mark Batterson. Security Solutions for ATM. Threat Analysis Group. 2003.

[8] J. R. Batmetan Suyoto, J. D. C. L. Suares, "An Empirical Investigation on Customer Behavior to Adopt Mobile Commerce among the Y Generation in Indonesia", Sriwijaya International Conference On Engineering, Science \& Technology [SICEST 2016], 2016

[9] J.R. Batmetan, "Algoritma Ant Colony Optimization (ACO) untuk Pemilihan Jalur Tercepat Evakuasi Bencana Gunung Lokon Sulawesi Utara", Jurnal Teknologi Informasi-AITI, 2016, vol.13, no.2, pp 31-48

[10] L. Madeso, D. R. Kabo, J. R. Batmetan, " Rancang Bangun Sistem Pakar Penentuan Status Gizi Pada Balita Menggunakan Metode Forward Chainning", E-Jurnal UNSRIT, vol.2

[11] J. R. Batmetan, V. R. Palilingan, " Higher Education Students' Behaviour to Adopt Mobile Learning", IOP Conference Series: Materials Science and
Engineering, 2018, vol. 306, Issue 1, pp. 012110 (2018)

[12] V. R. Palilingan, J. R. Batmetan, " Incident Management in Academic Information System using ITIL Framework", IOP Conference Series: Materials Science and Engineering, 2018, vol. 306, Issue 1, pp. 012110 (2018)

[13] J. R. Batmetan, A. J. Santoso, Pranowo, " A Multiple-Objective Ant Colony Algorithm for Optimizing Disaster Relief Logistics", Advanced Science Letters, 2017, vol.23, no.3, pp. 2344-2347

[14] M. L. Tompodung, F. Supit, J. R. Batmetan, " Rancang Bangun Aplikasi Sensus Penduduk Berbasis Android", Buletin Sariputra, 2017, vol.7, pp. 57-61

[15] J. R. Batmetan, " Optimasi Strategi Smart Environment Dalam Mitigasi Bencana Menggunakan Multi-Objective Aco (Mo-Aco) Algorithm", Pasca Sarjana Magister Teknik Informatika Universitas Atma Jaya Yogyakarta, 2016 